\title{
Circum-Arctic Resource Appraisal: Estimates of Undiscovered Oil and Gas North of the Arctic Circle
}

\author{
The U.S. Geological Survey (USGS) \\ has completed an assessment of \\ undiscovered conventional oil and \\ gas resources in all areas north of \\ the Arctic Circle. Using a geology- \\ based probabilistic methodology, \\ the USGS estimated the occurrence \\ of undiscovered oil and gas in 33 \\ geologic provinces thought to be \\ prospective for petroleum. The sum of \\ the mean estimates for each province \\ indicates that 90 billion barrels of \\ oil, 1,669 trillion cubic feet of natural \\ gas, and 44 billion barrels of natural \\ gas liquids may remain to be found \\ in the Arctic, of which approximately \\ 84 percent is expected to occur in \\ offshore areas.
}

\section{Introduction}

In May 2008 a team of U.S. Geological Survey (USGS) scientists completed an appraisal of possible future additions to world oil and gas reserves from new field discoveries in the Arctic. This Circum-Arctic Resource Appraisal (CARA) evaluated the petroleum potential of all areas north of the Arctic Circle ( $66.56^{\circ}$ north latitude); quantitative assessments were conducted in those geologic areas considered to have at least a 10-percent chance of one or more significant oil or gas accumulations. For the purposes of the study, a significant accumulation contains recoverable volumes of at least 50 million barrels of oil and/or oilequivalent natural gas. The study included only those resources believed to be recoverable using existing technology, but with the important assumptions for offshore areas that the resources would be recoverable even in the presence of permanent sea ice and oceanic water depth. No economic considerations are included in these initial estimates; results are presented without reference to costs of exploration and devel-

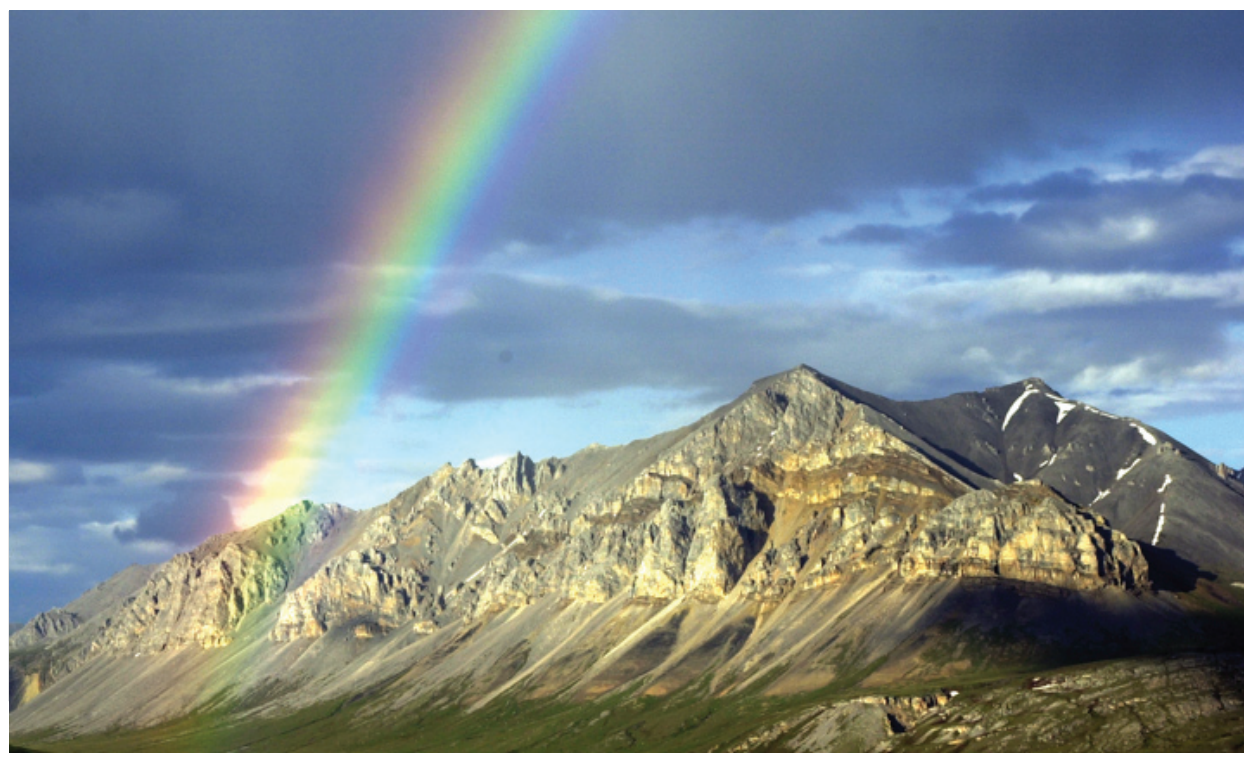

Overturned sedimentary rocks of the Lisburne Group under a midnight rainbow near Galbraith Lake, Alaska, summer 2001. USGS photo by David Houseknecht.

opment, which will be important in many of the assessed areas. So-called nonconventional resources, such as coal bed methane, gas hydrate, oil shale, and tar sand, were explicitly excluded from the study. Full details of the CARA study will be published later.

A number of onshore areas in Canada, Russia, and Alaska already have been explored for petroleum, resulting in the discovery of more than 400 oil and gas fields north of the Arctic Circle. These fields account for approximately 240 billion barrels (BBOE) of oil and oil-equivalent natural gas, which is almost 10 percent of the world's known conventional petroleum resources (cumulative production and remaining proved reserves). Nevertheless, most of the Arctic, especially offshore, is essentially unexplored with respect to petroleum. The Arctic Circle encompasses about 6 percent of the Earth's surface, an area of more than 21 million $\mathrm{km}^{2}\left(8.2\right.$ million $\left.\mathrm{mi}^{2}\right)$, of which almost 8 million $\mathrm{km}^{2}$ (3.1 million $\mathrm{mi}^{2}$ ) is onshore and more than 7 million $\mathrm{km}^{2}$ (2.7 million $\mathrm{mi}^{2}$ ) is on continental shelves under less than $500 \mathrm{~m}$ of water. The extensive Arctic continental shelves may constitute the geographically largest unexplored prospective area for petroleum remaining on Earth.

\section{Methodology}

A newly compiled map of Arctic sedimentary basins (Arthur Grantz and others, unpublished work) was used to define geologic provinces, each containing more than $3 \mathrm{~km}$ of sedimentary strata. Assessment units (AUs)mappable volumes of rock with common geologic traits-were identified within each province and quantitatively assessed for petroleum potential. Because of the sparse seismic and drilling data in much of the Arctic, the usual tools and techniques used in USGS resource assessments, such as discovery process modeling, prospect delineation, and deposit simulation, were not generally applicable. Therefore, the CARA relied on a probabilistic methodology of geological analysis and analog modeling. A world analog database (Charpentier and others, 2008) was developed using the AUs defined in the USGS World Petroleum Assessment 2000 (USGS World Assessment Team, 2000). [Continued on back page] 


\section{PETROLEUM POTENTIAL OF ASSESSMENT UNITS AND PROVINCES IN THE CIRCUM-ARCTIC}

In the Circum-Arctic Resource Appraisal (CARA), 33 provinces were examined, of which 25 were judged to have a 10-percent or greater probability of at least one significant undiscovered petroleum accumulation in any constituent assessment unit (AU) and were therefore quantitatively assessed. Shown in these three maps are the relative probabilities for all assessment units assessed and the estimated relative potentials for undiscovered oil and gas in the assessed provinces.

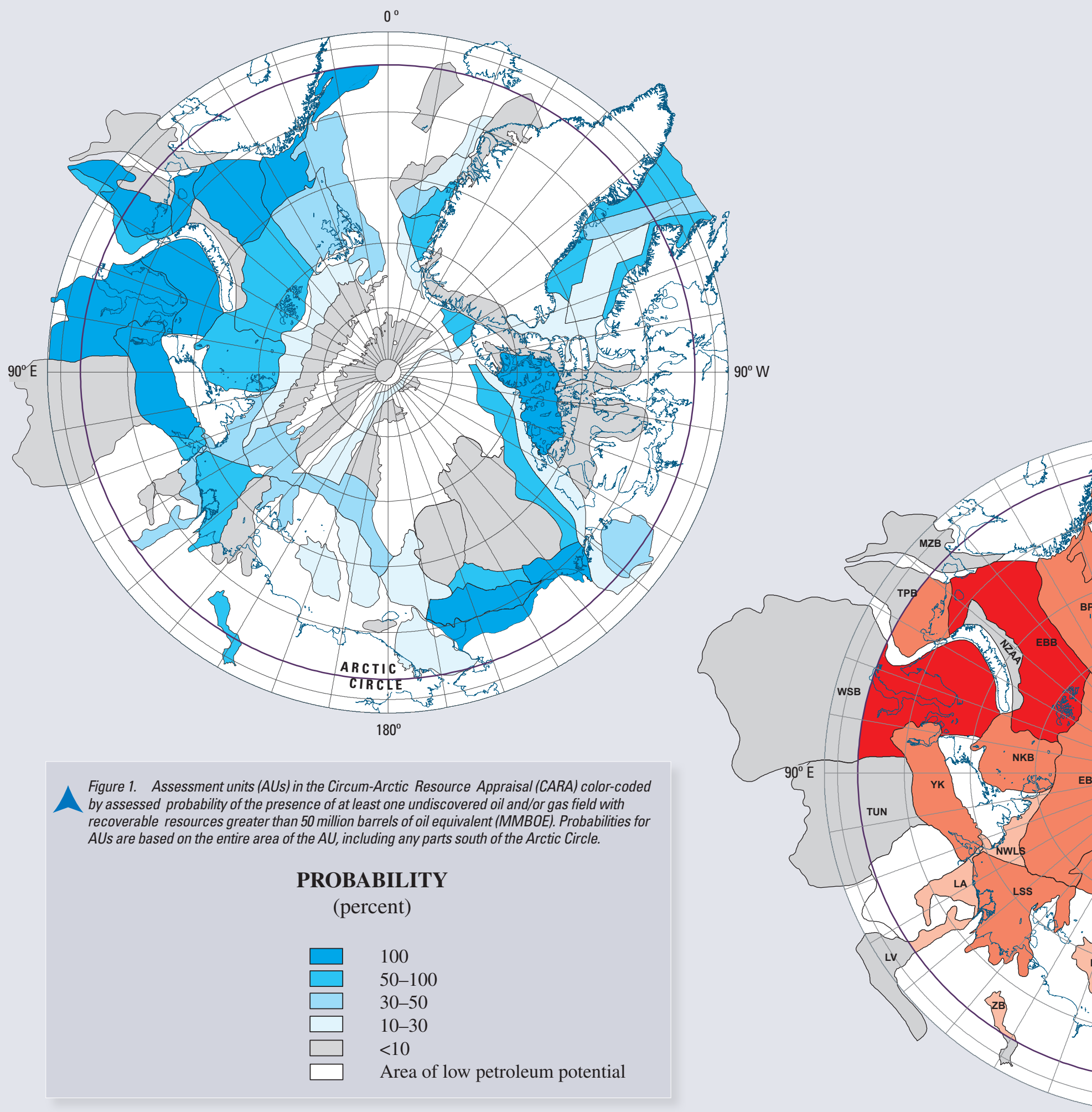




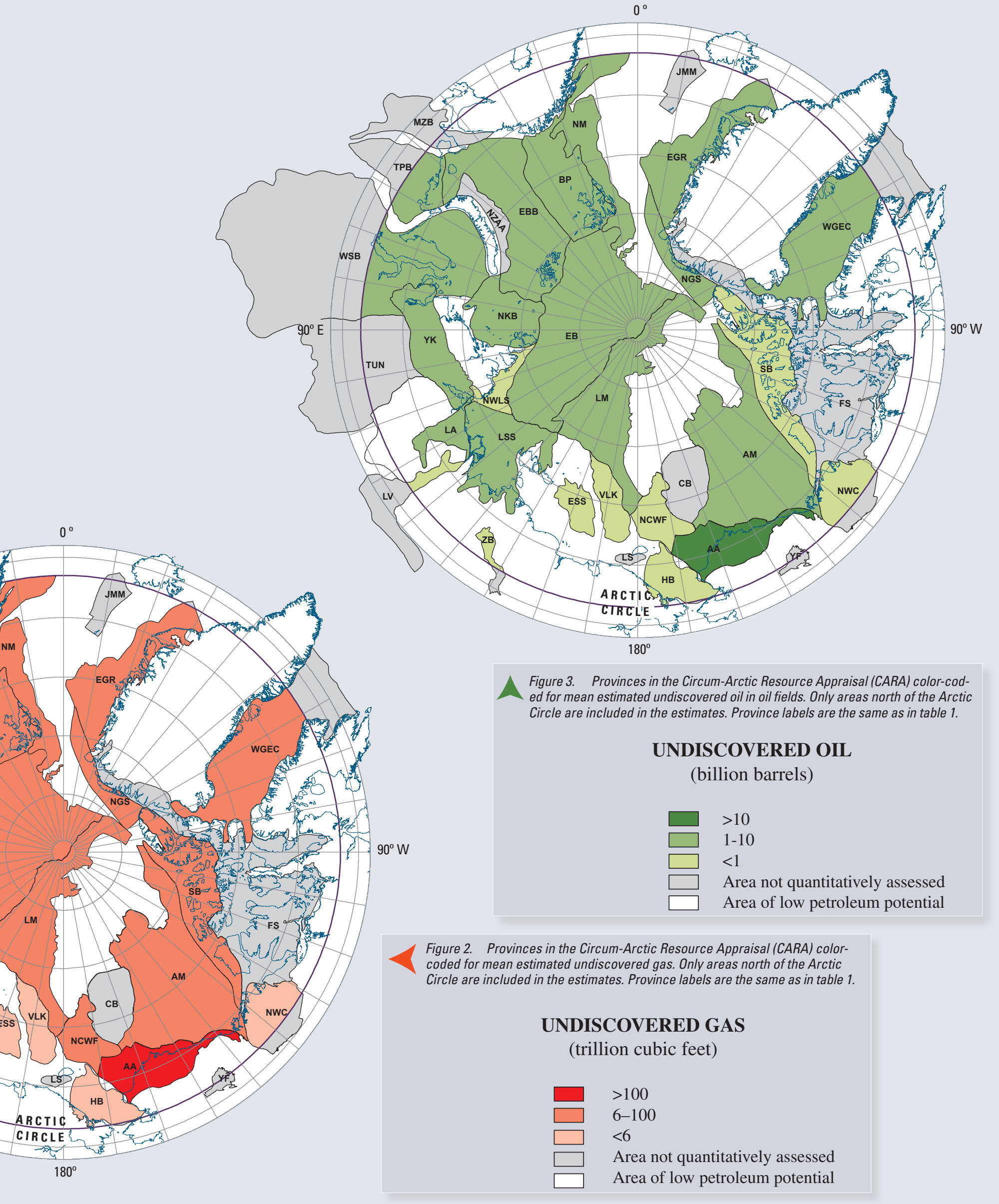




\section{[Continued from front page]}

The database includes areas that account for more than 95 percent of the world's known oil and gas resources outside the United States.

For each assessment unit, the CARA team assessed the probability (AU probability) that a significant oil or gas accumulation was present. This evaluation of AU probability was based on three geologic elements: (1) charge (including source rocks and thermal maturity), (2) rocks (including reservoirs, traps, and seals), and (3) timing (including the relative ages of migration and trap formation, as well as preservation). Each assessment unit was ranked according to its AU probability; those AUs judged to have less than a 10-percent probability of a significant accumulation were not quantitatively assessed.
In addition to the AU probability, the number of accumulations, the size-frequency distribution of accumulations, and the relative likelihood of oil versus gas were assessed for each AU and combined by means of a Monte Carlo simulation. The probabilistic results reflect the wide range of uncertainty inherent in frontier geological provinces such as those of the Arctic.

\section{Results-Resource Summary}

Within the area of the CARA, 25 provinces were quantitatively assessed; 8 provinces were judged to have less than a 10-percent probability of at least one significant accumulation in any AU and were, therefore, not assessed. Results of individual AU assess-

\section{Table 1. Summary of Results of the Circum-Arctic Resource Appraisal}

[MMBO, million barrels of oil; BCFG, billion cubic feet of natural gas; MMBNGL, million barrels of natural gas liquids; NQA, not quantitatively assessed. Results shown are fully risked mean estimates. For gas accumulations, all liquids are included as NGL (natural gas liquids). Provinces are listed in ranked order of total barrels of oil and oil-equivalent natural gas (BOE).]

\begin{tabular}{|c|c|c|c|c|c|}
\hline $\begin{array}{l}\text { Province } \\
\text { Code }\end{array}$ & Province & $\begin{array}{c}\text { Oil } \\
\text { (MMBO) }\end{array}$ & $\begin{array}{l}\text { Total Gas } \\
\text { (BCFG) }\end{array}$ & $\begin{array}{c}\text { NGL } \\
\text { (MMBNGL) }\end{array}$ & $\begin{array}{c}\text { BOE } \\
\text { (MMBOE) }\end{array}$ \\
\hline WSB & West Siberian Basin & $3,659.88$ & $651,498.56$ & $20,328.69$ & $132,571.66$ \\
\hline AA & Arctic Alaska & $29,960.94$ & $221,397.60$ & $5,904.97$ & $72,765.52$ \\
\hline EBB & East Barents Basin & $7,406.49$ & $317,557.97$ & $1,422.28$ & $61,755.10$ \\
\hline EGR & East Greenland Rift Basins & $8,902.13$ & $86,180.06$ & $8,121.57$ & $31,387.04$ \\
\hline YK & Yenisey-Khatanga Basin & $5,583.74$ & $99,964.26$ & $2,675.15$ & $24,919.61$ \\
\hline AM & Amerasia Basin & $9,723.58$ & $56,891.21$ & 541.69 & $19,747.14$ \\
\hline WGEC & West Greenland-East Canada & $7,274.40$ & $51,818.16$ & $1,152.59$ & $17,063.35$ \\
\hline LSS & Laptev Sea Shelf & $3,115.57$ & $32,562.84$ & 867.16 & $9,409.87$ \\
\hline NM & Norwegian Margin & $1,437.29$ & $32,281.01$ & 504.73 & $7,322.19$ \\
\hline BP & Barents Platform & $2,055.51$ & $26,218.67$ & 278.71 & $6,704.00$ \\
\hline EB & Eurasia Basin & $1,342.15$ & $19,475.43$ & 520.26 & $5,108.31$ \\
\hline NKB & North Kara Basins and Platforms & $1,807.26$ & $14,973.58$ & 390.22 & $4,693.07$ \\
\hline TPB & Timan-Pechora Basin & $1,667.21$ & $9,062.59$ & 202.80 & $3,380.44$ \\
\hline NGS & North Greenland Sheared Margin & $1,349.80$ & $10,207.24$ & 273.09 & $3,324.09$ \\
\hline LM & Lomonosov-Makarov & $1,106.78$ & $7,156.25$ & 191.55 & $2,491.04$ \\
\hline SB & Sverdrup Basin & 851.11 & $8,596.36$ & 191.20 & $2,475.04$ \\
\hline LA & Lena-Anabar Basin & $1,912.89$ & $2,106.75$ & 56.41 & $2,320.43$ \\
\hline NCWF & \begin{tabular}{|l} 
North Chukchi-Wrangel Foreland \\
Basin \\
\end{tabular} & 85.99 & $6,065.76$ & 106.57 & $1,203.52$ \\
\hline VLK & Vilkitskii Basin & 98.03 & $5,741.87$ & 101.63 & $1,156.63$ \\
\hline NWLS & Northwest Laptev Sea Shelf & 172.24 & $4,488.12$ & 119.63 & $1,039.90$ \\
\hline LV & Lena-Vilyui Basin & 376.86 & $1,335.20$ & 35.66 & 635.06 \\
\hline ZB & Zyryanka Basin & 47.82 & $1,505.99$ & 40.14 & 338.95 \\
\hline ESS & East Siberian Sea Basin & 19.73 & 618.83 & 10.91 & 133.78 \\
\hline HB & Hope Basin & 2.47 & 648.17 & 11.37 & 121.87 \\
\hline NWC & Northwest Canada Interior Basins & 23.34 & 305.34 & 15.24 & 89.47 \\
\hline MZB & Mezen' Basin & NQA & NQA & NQA & $\mathrm{NQA}$ \\
\hline NZAA & $\begin{array}{l}\text { Novaya Zemlya Basins and Admiralty } \\
\text { Arch }\end{array}$ & NQA & NQA & NQA & NQA \\
\hline TUN & Tunguska Basin & NQA & NQA & NQA & NQA \\
\hline CB & Chuckhi Borderland & NQA & NQA & NQA & NQA \\
\hline YF & \begin{tabular}{|c|} 
Yukon Flats (part of Central Alaska \\
Province)
\end{tabular} & NQA & NQA & NOA & NOA \\
\hline LS & Long Strait & NQA & NQA & NQA & NOA \\
\hline JMM & Jan Mayen Microcontinent & NOA & NQA & NOA & NQA \\
\hline FS & Franklinian Shelf & NQA & $\mathrm{NQA}$ & NQA & NQA \\
\hline \multicolumn{2}{|l|}{ Total } & $89,983.21$ & $1,668,657.84$ & $44,064.24$ & $412,157.09$ \\
\hline
\end{tabular}

ments are not reported here, but the AUs are shown as mapped areas on figure 1, where they are color-coded for the probability of at least one undiscovered accumulation of minimum size. The provinces are listed in table 1 , in ranked order of total mean estimated oil-equivalent volumes of undiscovered oil, gas, and natural gas liquids (NGL). The provinces are shown in figures 2 and 3, where they have been color-coded with respect to fully risked (including AU probabilities) potential for gas and oil, respectively.

More than 70 percent of the mean undiscovered oil resources is estimated to occur in five provinces: Arctic Alaska, Amerasia Basin, East Greenland Rift Basins, East Barents Basins, and West Greenland-East Canada. More than 70 percent of the undiscovered natural gas is estimated to occur in three provinces, the West Siberian Basin, the East Barents Basins, and Arctic Alaska. It is further estimated that approximately 84 percent of the undiscovered oil and gas occurs offshore. The total mean undiscovered conventional oil and gas resources of the Arctic are estimated to be approximately 90 billion barrels of oil, 1,669 trillion cubic feet of natural gas, and 44 billion barrels of natural gas liquids.

\section{References}

Charpentier, R.R., Klett, T.R., and Attanasi, E.D., 2008, Database for assessment unit-scale analogs (exclusive of the United States): U.S. Geological Survey Open-File Report 2007-1404 [http://pubs.usgs.gov/of/2007/1404/].

USGS World Assessment Team, 2000, U.S. Geological Survey World Petroleum Assessment 2000-Description and Results: U.S. Geological Survey Digital Data Series - DDS60 [http://pubs.usgs.gov/dds/dds-060/].

Circum-Arctic Resource
Appraisal Assessment Team
(in alphabetical order):
Kenneth J. Bird, Ronald R. Charpentier,
Donald L. Gautier (CARA Project Chief),
David W. Houseknecht, Timothy R. Klett,
Janet K. Pitman, Thomas E. Moore,
Christopher J. Schenk, Marilyn E. Tennyson,
and Craig J. Wandrey

Edited by Peter H. Stauffer Graphic design by Judy Weathers and Zenon Valin

For further information contact: Donald L. Gautier: gautier@usgs.gov U.S. Geological Survey, Mail Stop 969 345 Middlefield Road Menlo Park, CA 94025

This fact sheet and any updates to it are available online at: http://pubs.usgs.gov/fs/2008/3049/ 